\title{
Dual antiplatelet therapy duration after coronary stenting in clinical practice: results of an EAPCI survey
}

\author{
Marco Valgimigli ${ }^{*}$, MD, PhD; Francesco Costa ${ }^{1}$, MD; Robert Byrne ${ }^{2}$, MD; Michael Haude ${ }^{3}$, MD; \\ Andreas Baumbach ${ }^{4}, \mathrm{MD}$; Stephan Windecker ${ }^{5}, \mathrm{MD}, \mathrm{PhD}$ \\ 1. Thoraxcenter, Erasmus Medical Center, Rotterdam, The Netherlands; 2. Deutsches Herzzentrum München, Technische \\ Universität München, Munich, Germany; 3. Medical Clinic I, Städtische Kliniken Neuss, Lukaskrankenhaus GmbH, Neuss, \\ Germany; 4. Bristol Heart Institute, University Hospital Bristol, Bristol, United Kingdom; 5. Department of Cardiology, Bern \\ University Hospital, Bern, Switzerland
}

This paper also includes accompanying supplementary data published online at: http://www.pcronline.com/eurointervention/84th_issue/11

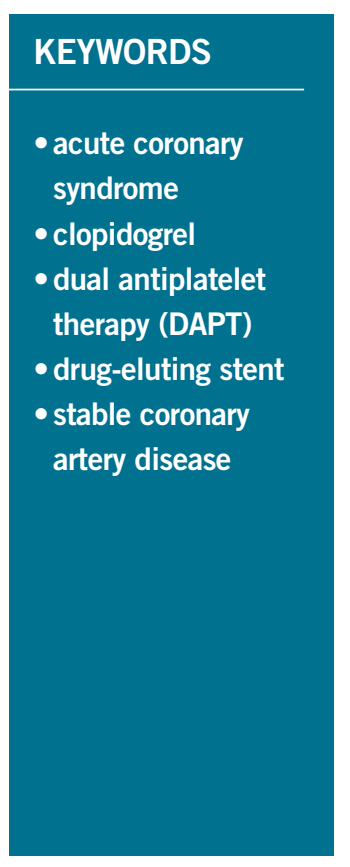

\begin{abstract}
Aims: Our aim was to report on a survey initiated by the European Association of Percutaneous Cardiovascular Interventions (EAPCI) concerning opinion on the evidence relating to dual antiplatelet therapy (DAPT) duration after coronary stenting.

Methods and results: Results from three randomised clinical trials were scheduled to be presented at the American Heart Association Scientific Sessions 2014 (AHA 2014). A web-based survey was distributed to all individuals registered in the EuroIntervention mailing list $(n=15,200)$ both before and after AHA 2014. A total of 1,134 physicians responded to the first (i.e., before AHA 2014) and 542 to the second (i.e., after AHA 2014) survey. The majority of respondents interpreted trial results consistent with a substantial equipoise regarding the benefits and risks of an extended versus a standard DAPT strategy. Two respondents out of ten believed extended DAPT should be implemented in selected patients. After AHA 2014, 46.1\% of participants expressed uncertainty about the available evidence on DAPT duration, and $40.0 \%$ the need for clinical guidance.
\end{abstract}

Conclusions: This EAPCI survey highlights considerable uncertainty within the medical community with regard to the optimal duration of DAPT after coronary stenting in the light of recent reported trial results. Updated recommendations for practising physicians to guide treatment decisions in routine clinical practice should be provided by international societies.

\footnotetext{
*Corresponding author: Thoraxcenter, Ba 587, Erasmus MC, 's-Gravensdijkwal 230, 3015 CE Rotterdam, The Netherlands. E-mail:m.valgimigli@erasmusmc.nl
} 


\section{Introduction}

The importance of dual antiplatelet therapy (DAPT) in patients with acute coronary syndromes and after coronary stent implantation has been substantiated in numerous trials ${ }^{1,2}$ and has also been endorsed by international guidelines ${ }^{3,4}$. However, the optimal duration of DAPT after coronary stenting, which maximises the benefits in terms of ischaemic protection and minimises the risks in terms of bleeding, remains unclear.

\section{Editorial, see page 15}

Between 2010 and 2014 results have been reported from a number of randomised clinical trials comparing different DAPT duration regimens after coronary stent implantation ${ }^{5}$. Data from these studies failed to show clear evidence of benefit in terms of ischaemic events, in prolonging DAPT beyond one year. Moreover, a DAPT regimen shorter than 12 months was shown to be safer than the currently recommended 12-month DAPT duration ${ }^{6}$. During the American Heart Association Scientific Sessions 2014 (AHA 2014), results from three additional clinical trials investigating the optimal DAPT duration after stenting in an aggregate of approximately 20,000 randomised patients - DAPT, ISAR-SAFE and ITALIC $^{7-9}-$ were reported for the first time.

In the light of the anticipated impact of the data from these three trials on clinical practice, the European Association of Percutaneous Coronary Interventions (EAPCI) sought to assess the opinions of the scientific community concerning DAPT duration both before and after AHA 2014. To do this, the association undertook a voluntary web-based survey of the community regarding opinions on DAPT duration after coronary stenting. The current manuscript is a summary of the results.

\section{Methods}

This survey initiative was designed to address three major domains concerning DAPT duration: i) clinical practice regarding DAPT duration based on the evidence available before AHA 2014; ii) the expectations of and the reactions to the results of DAPT ${ }^{7}$, ISAR$\mathrm{SAFE}^{8}$ and ITALIC ${ }^{9}$, whose primary findings were presented for the first time during AHA 2014; and iii) the anticipated impact of this new evidence on clinical practice according to the opinion of practising physicians. Accordingly, this survey was built into two sets of questions, distributed before and after the AHA 2014 congress.

The questions included were drafted by the EAPCI Scientific Document Committee and subsequently approved by the EAPCI board. The survey was undertaken using a free web-based survey tool (SurveyMonkey, Palo Alto, CA, USA) and comprised multiple choice questions, including the possibility of adding further comments if required. It was not mandatory to reply to the entire survey. The sample population comprised the mailing list of EuroIntervention - the official journal of the EAPCI. Overall, a total of 15,200 individuals were invited to participate. The invitation to the first part of the survey was sent on the $30^{\text {th }}$ October 2014 and a reminder was sent on the $7^{\text {th }}$ November 2014. For the second part of the survey, the invitation was sent on the $2^{\text {nd }}$ February 2015 and a reminder on the $9^{\text {th }}$ February 2015.

\section{Results \\ RESPONDENT CHARACTERISTICS}

Of the 15,200 invitations sent, a total of 1,134 (7.5\%) and 542 (3.6\%) physicians responded to the first and the second part of the survey, respectively. Among those, 884 (78\%) for the first and 415 (76.6\%) for the second part of the survey provided personal and professional information with respect to age, medical and institutional qualification, and geographic region of practice (Online appendix). The characteristics of the respondents are detailed in Table 1. Participation in the survey was global, with the majority of respondents being European (65.1\% for the first and $71.5 \%$ for the second part of the survey) (Table 1, Online Figure 1). The majority of participants were interventional cardiologists at various career stages ( $87.4 \%$ and $90.3 \%$, respectively), followed by cardiologists in training $(5.8 \%$ and $4.6 \%$, respectively) and non-interventional cardiologists (5.7\% and $4.1 \%$, respectively). A minority of responders declared professional qualifications other than cardiological ones ( $1.2 \%$ and $1 \%$, respectively) (Table 1 ). About half of participants worked in an academic environment, while the remaining $50 \%$ were affiliated to non-university-based centres or private institutions (Table 1). The mean age of respondents was 45 years.

\section{DECLARED CLINICAL PRACTICE OF RESPONDENTS CONCERNING DAPT DURATION BEFORE AHA 2014}

The main findings of this part of the survey are shown in Online Table 1 . The majority (53.2\%) of respondents indicated a recommendation for a 12-month DAPT duration in all patients treated with drug-eluting stents (DES); one quarter (23.5\%) selected

Table 1. Respondent characteristics.

\begin{tabular}{|c|c|c|}
\hline & $\begin{array}{l}\text { Survey before } \\
\text { AHA }(n=884)\end{array}$ & $\begin{array}{l}\text { Survey after } \\
\text { AHA ( } n=415)\end{array}$ \\
\hline Age & 45.0 & 46.2 \\
\hline \multicolumn{3}{|l|}{ Country of work } \\
\hline Europe & $65.1 \%$ & $71.5 \%$ \\
\hline North America & $8.0 \%$ & $9.1 \%$ \\
\hline South America & $8.4 \%$ & $8.4 \%$ \\
\hline Asia & $13.9 \%$ & $4.9 \%$ \\
\hline Africa & $3.9 \%$ & $4.2 \%$ \\
\hline Australia & $0.7 \%$ & $1.9 \%$ \\
\hline \multicolumn{3}{|l|}{ Professional figure } \\
\hline Interventional cardiologist ( $>10$ years of experience) & $49.8 \%$ & $56.6 \%$ \\
\hline Interventional cardiologist ( $>5$ years of experience) & $20.7 \%$ & $17.3 \%$ \\
\hline Interventional cardiologist ( $<5$ years of experience) & $16.9 \%$ & $16.4 \%$ \\
\hline Cardiologist in training & $5.8 \%$ & $4.6 \%$ \\
\hline Non-interventional cardiologist & $5.7 \%$ & $4.1 \%$ \\
\hline Other & $1.2 \%$ & $1.0 \%$ \\
\hline \multicolumn{3}{|l|}{ Type of practice } \\
\hline University hospital & $49.3 \%$ & $53.7 \%$ \\
\hline Non-academic public hospital & $31.5 \%$ & $29.6 \%$ \\
\hline Private institution & $19.3 \%$ & $21.2 \%$ \\
\hline
\end{tabular}


a six-month regimen in patients presenting with stable disease and a 12-month regimen for ACS patients; $10.3 \%$ routinely prolonged DAPT beyond one year. Three quarters of respondents declared that they take both ischaemic and bleeding risk into consideration when prescribing DAPT. History of stent thrombosis (86\%), stenting of the left main or proximal left anterior descending coronary artery (79.7\%) and stable versus unstable presentation (74.8\%) were the covariates most frequently used in practice to weigh the ischaemic risk (Figure 1). On the other hand, previous bleeding (82.5\%), age $(76.4 \%)$ and renal function $(65.3 \%)$ have more frequently been identified as important to forecast bleeding (Figure 2). This clinical and/or angiographic set of key covariates used to predict ischaemic or bleeding risk was consistent across institution characteristics (i.e., academic or not academic) and medical qualification/experience (i.e., interventional cardiologist with more than 10 years of experience vs. others, or cardiologist in training vs. others).

With respect to changes to the initially prescribed treatment, $36 \%$ of participants reported weighing the occurrence of minor or nuisance bleeding while on DAPT in the decision making on DAPT duration after its prescription, whereas the majority declared adhering to the originally prescribed DAPT duration.

The belief that first-generation DES are more thrombogenic than newer-generation devices and as such require long-term DAPT was widely held $(93.5 \%)$. However, $54.8 \%$ of participants thought that there are still insufficient data to conclude that vulnerability to short DAPT is stent-specific within the class of newer-generation DES. The majority agreed that six-month DAPT is a safe pharmacological strategy after implantation of newer-generation DES, but expressed a need for more clinical data, particularly if a duration shorter than six months is to be recommended, for example after implantation of new-generation non-polymeric DES. The majority also stated that there are insufficient data to draw conclusions on the optimal DAPT duration regimen after bioresorbable everolimus vascular scaffold implantation.

Respondents generally agreed that long-term DAPT exerts protective effects well beyond the prevention of stent-related ischaemic recurrences.

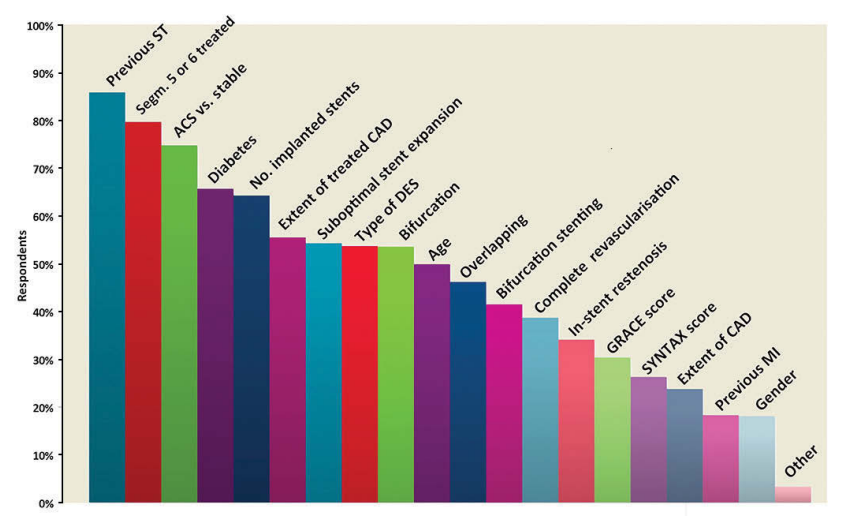

Figure 1. Please select which of the following variables or scores you generally use to weigh the ischaemic risk after DES implantation (multiple answers allowed).

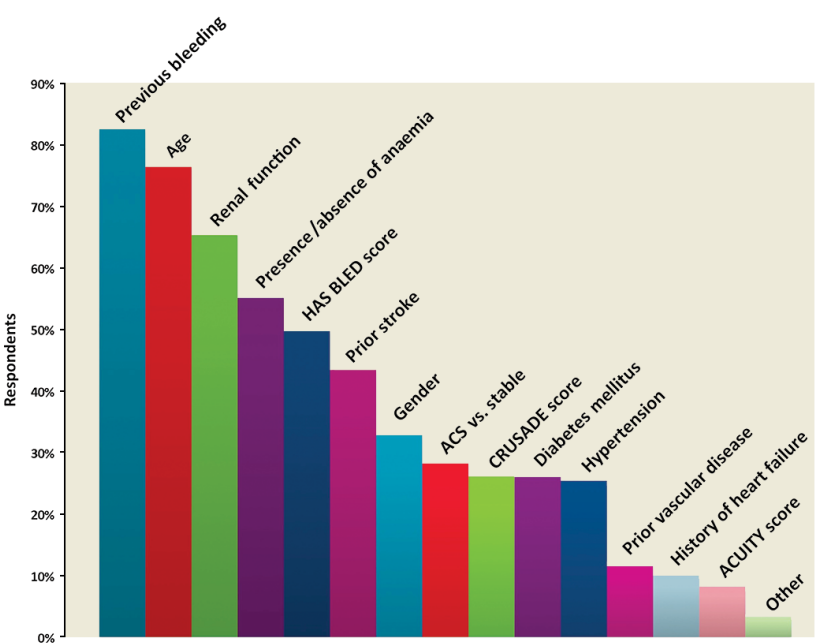

Figure 2. Please select which of the following variables or scores you generally use to weigh the bleeding risk after DES implantation (multiple answers allowed).

In patients deemed at high risk of bleeding, six responders out of ten (with a gradient noted across professional activity, 75\% non-interventional cardiologists and 55\% cardiologists in training) would prefer to implant bare metal stents followed by 30-day DAPT.

\section{ANTICIPATION AND INTERPRETATION OF TRIAL RESULTS PRESENTED AT AHA 2014}

Before AHA 2014, 41.4\% of respondents believed that the evidence guiding DAPT duration in patients receiving DES was average, and $22.8 \%$ asserted that it was confusing. The expectations for the upcoming trials were aligned to the results of previous randomised studies available at that time. Indeed, $72.6 \%$ expected the DAPT trial not to show the superiority of 30 -month vs. 12-month DAPT and $85 \%$ expected ISAR-SAFE to show non-inferiority of a sixmonth DAPT strategy as compared to a 12-month strategy (Online Table 1).

In relation to the DAPT trial, following AHA 2014, 48.5\% of respondents interpreted the results of the trial as showing substantial remaining equipoise between the two treatment strategies (i.e., extended duration [30 months] vs. standard duration [12 months]) in terms of efficacy and safety. Against this, $28.4 \%$ responded that a standard 12-month DAPT duration remained the preferred clinical strategy (Figure 3), 23.1\% reported that that they were convinced of the superiority of 30-month DAPT duration, and $6.1 \%$ believed that it should become the new standard of care. These results were consistent across geographic regions. The reasons reported for not adopting the extended duration used in the DAPT trial as a new standard of care were: concern regarding bleeding risk for $75.4 \%$ of respondents, the use of a high proportion of early-generation DES in the trial for $55.4 \%$ of respondents, concern about the higher mortality observed in the 30 -month group for $41.6 \%$ of respondents, limited use of new $\mathrm{P} 2 \mathrm{Y}_{12}$ inhibitors for $29.1 \%$ of respondents, and 


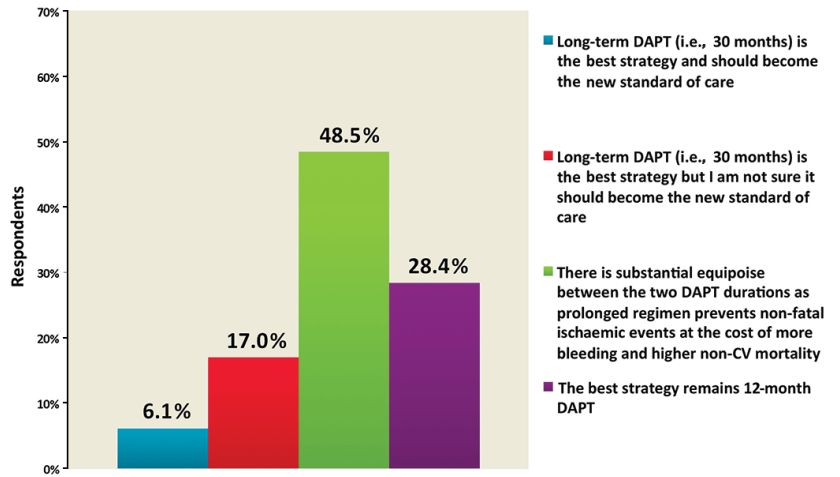

Figure 3. What is your interpretation of the results of the DAPT trial which were presented at AHA and simultaneously published in the New England Journal of Medicine?

the highly selected patient population for $34.2 \%$ of respondents, and/or concerns regarding the reproducibility of these results in clinical practice outside trials for $24.6 \%$ of respondents (Figure 4).

The excess of non-cardiovascular mortality observed in the extended duration treatment arm of the DAPT trial was interpreted as a finding which raises concerns by $32.2 \%$ of respondents, while $33.8 \%$ would like to know more about this issue (Figure 5 ). The benefit in terms of reduction of stent thrombosis was related to first-generation DES use in the view of $35 \%$ of the respondents, while $30.6 \%$ thought that it was not applicable to current practice with new-generation DES, whereas $23.8 \%$ thought that this benefit applied to all stent types (Figure 6).

Evaluating the results of all three studies presented during AHA 2014 in aggregate, $44.4 \%$ of respondents believed that the results were compatible with both the possible benefit of long-term DAPT and also the feasibility of stopping therapy early if needed (Figure 7); $22.7 \%$ of respondents did not declare a clear opinion and $20.1 \%$ found the results contradictory and/or confusing.

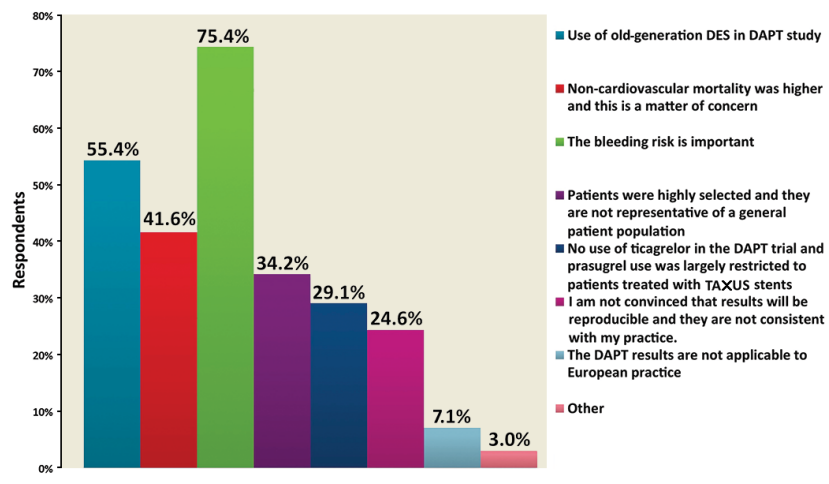

Figure 4. What is/are the reason(s) behind your belief that 30-month $D A P T$ should not become the new standard of care after DAPT trial (multiple answers allowed).

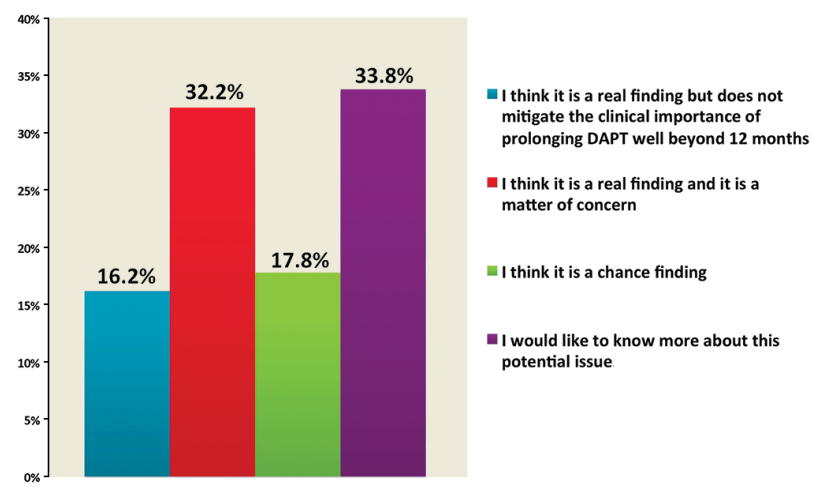

Figure 5. What is your interpretation of the mortality findings in the DAPT trial (i.e., excess of non-cardiovascular mortality in the 30-month DAPT group)?

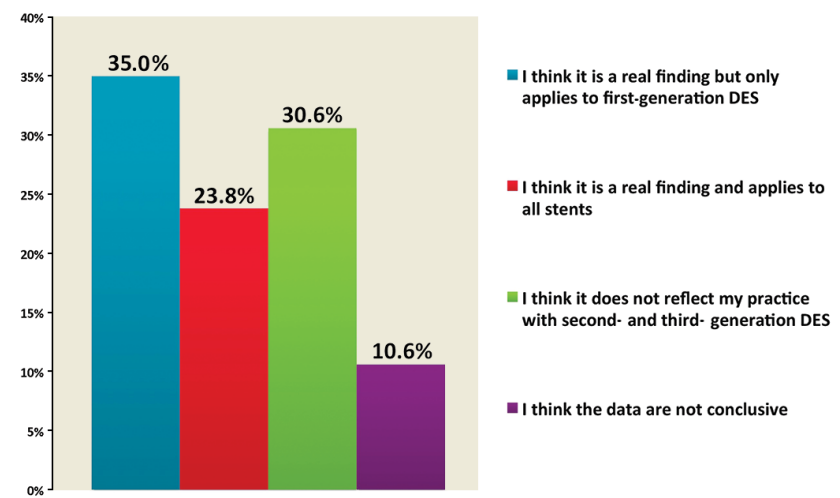

Figure 6. What is your interpretation of the stent thrombosis findings in the DAPT trial (i.e., lower risk of ST with prolonged DAPT irrespective of stent type)?

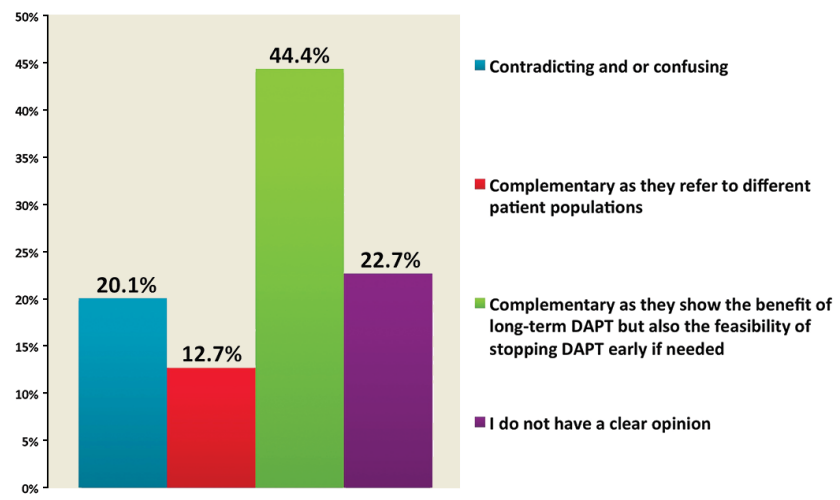

Figure 7. How do you find the results of the DAPT trial as compared to the ISAR-SAFE and ITALIC/ITALIC+ trials?

\section{PRACTICE AFTER THE DAPT, ISAR-SAFE AND ITALIC TRIALS}

The main findings of this part of the survey are shown in Online Table 2. The majority of respondents (58.1\%) indicated that DAPT duration should be individualised, i.e., prolonged in selected patients 
and shortened in selected patients, as opposed to a 12-month DAPT regimen in all, whereas $12.5 \%$ believed that practice and recommendations should not change after the new evidence provided at AHA 2014. Forty percent of respondents believed that a prolonged therapy, beyond one year, should be limited to less than $10 \%$ of the patient population; whereas $34 \%$ of respondents would treat 10 to $30 \%$ of their patients with this strategy (Online Table 2).

Comparing the answers to the parts of the survey delivered before and after AHA, a uniform 12-month DAPT duration in all patients was less frequently selected after AHA 2014 (37.3\% before vs. $22.9 \%$ after).

The most frequently preferred therapeutic options were: 1) sixmonth DAPT in stable and 12-month DAPT in ACS patients $(24.8 \%$ before AHA vs. 29.4\% after AHA), 2) DAPT beyond one year in a sizeable proportion of patients $(7.4 \%$ before AHA vs. $13.0 \%$ after AHA), 3) a tailored DAPT duration for individual patients based on ischaemic and/or bleeding risk $(9.7 \%$ before AHA vs. $16.2 \%$ after AHA) (Figure 8). After AHA 2014, the evidence that prolonged DAPT protects against non-stent-related events $(64.5 \%$ before AHA vs. $71.8 \%$ after AHA) was regarded as more compelling than before (Figure 9).

In contrast with the opinions expressed before AHA 2014, after the meeting the quality of evidence on DAPT duration in DES recipients was interpreted as "average" by $27.4 \%$ of the respondents (as compared to $41.4 \%$ of responders before AHA), whereas the majority regarded it as confusing (22.8\% before AHA vs. $46.1 \%$ after AHA) (Figure 10).

Overall, $40 \%$ of participants called for a change in the guidelines regarding DAPT duration (Online Table 2): the majority of cardiologists working in an academic environment responded in support of a formal change in guidelines supporting practice around DAPT duration, whereas the opposite was voiced by the majority of nonacademic cardiologists. When asked about how guidelines should change based on the new evidence, $72 \%$ of respondents thought

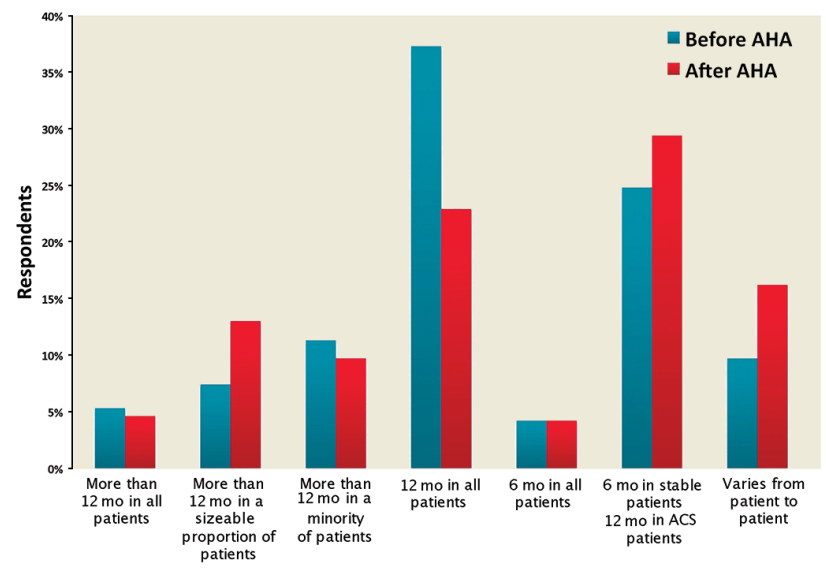

Figure 8. Comparison of the answers to the question "For how long do you generally prescribe DAPT after DES implantation in patients not requiring oral anticoagulation?" before and after AHA.

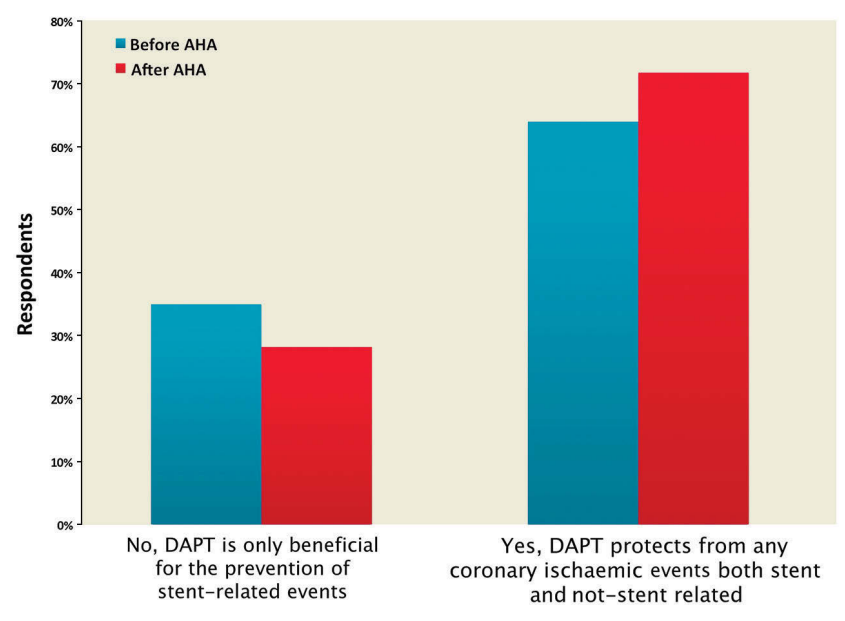

Figure 9. Comparison of the answers to the question "Do you think prolonged DAPT is beneficial for the prevention of ischaemic events, which are not stent-related?" before and after AHA.

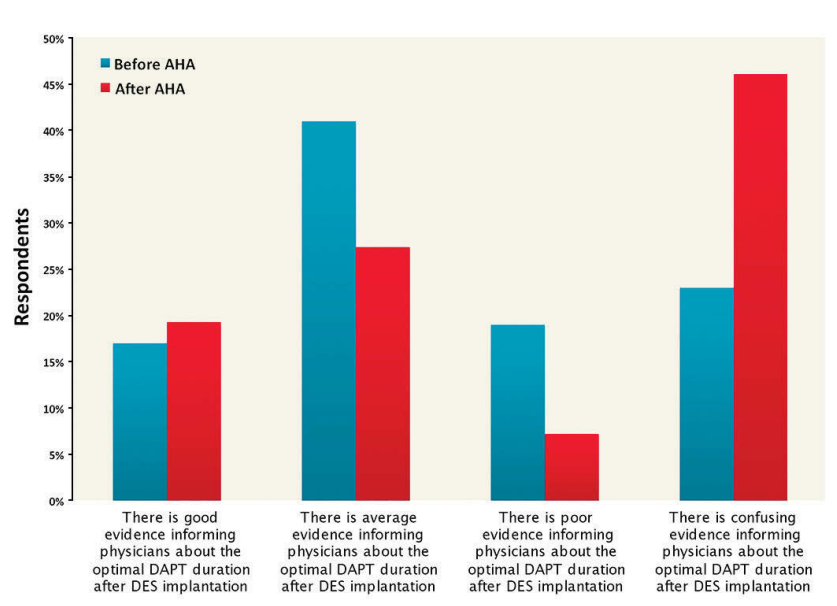

Figure 10. Comparison of the answers to the question "How do you judge the evidence regarding DAPT duration after DES implantation?" before and after AHA.

that guidelines should more proactively recommend an individualised therapy in different patient populations (Online Table 2).

Finally, $54.7 \%$ of participants believed that new randomised trials testing individualised therapy duration based on ischaemic and bleeding risk are needed, $35.6 \%$ expressed the need for trials comparing conventional DAPT versus a $\mathrm{P}_{2} \mathrm{Y}_{12}$ inhibitor alone long-term treatment strategy, whereas $34.8 \%$ solicited a consensus statement based on the evidence available (Online Table 2). The "other" option was selected by a few calling for new "real-world" prospective registries (two respondents), new randomised trials including potent $\mathrm{P} 2 \mathrm{Y}_{12}$ inhibitors (two respondents), new-generation DES (one respondent) or the implementation of intravascular imaging in decision making (one respondent). 


\section{INTERPRETATION OF THE SURVEY RESULTS}

The main findings of the EAPCI survey on DAPT duration can be summarised as follows:

- Before AHA 2014, the practice most commonly recommended was 12-month DAPT duration after DES implantation, whereas only one responder out of ten declared a clinical practice consistent with routine DAPT duration beyond one year after stent implantation.

- After AHA 2014, most respondents did not report extended DAPT duration of up to 30 months as representing the preferred approach in comparison with a 12-month treatment duration, and fewer than two responders out of ten believed that this should become the new standard of care.

- After AHA 2014, the evidence regarding DAPT duration was more frequently interpreted as confusing.

- The majority of respondents reported that DAPT should be prolonged or shortened in selected patients according to both ischaemic and bleeding risks and that future guidelines should more proactively recommend strategies in this direction.

- The results of the survey indicate that following the data presented at AHA 2014 considerable confusion exists regarding the optimal duration of DAPT after coronary stenting. The community needs guidance on how DAPT should be individualised and this largely reflects the lack of coordination across DAPT studies performed so far. Many meta-analyses on this topic already exist based on aggregate data, reaching inconsistent conclusions depending on different study selection and methods of analysis. Hence, a collaborative effort among all principal investigators of DAPT studies would be desirable to characterise further the included patient population in each of these and to be able to identify the patients who would most benefit from prolonged versus shortened DAPT and vice versa.

\section{Limitations}

This survey has a number of important limitations which should be carefully weighed when interpreting the results. Firstly, only a small percentage of invited practitioners took part in this survey. Therefore, the results are not necessarily representative of the opinion of the whole community. However, low participation rate is a common limitation of surveys in general, especially when the population targeted is that of professionals at an advanced career stage. Secondly, the use of multiple choice questions may lead to question bias. To reduce this effect, respondents were able to add open answers if they felt it was appropriate. In addition, respondents may have been subject to social desirability response bias: for example, this may have overestimated the percentage of those who declared weighing ischaemic and bleeding risks before selecting DAPT duration. Thirdly, the comparison of questions dispensed before and after AHA 2014 was not performed on an individual but on an aggregate basis. As such, it is not possible to evaluate if the single respondent changed his/her opinion or if a new cohort of respondents drove the change in the second part of the survey. However, in view of the relatively high number of contributors, it is likely that we have captured real changes in opinion due to the new evidence provided. Fourthly, this survey was designed and administered before the publication of the results of the PEGASUS trial ${ }^{10}$, which explored the effects of a prolonged therapy with ticagrelor in patients with previous myocardial infarction. It is possible that the opinion of the respondents may have changed in the light of this new evidence. Finally, the focus of this survey was on duration and not on type of DAPT (i.e., based on which P2 $\mathrm{Y}_{12}$ inhibitor). A further EAPCI survey addressing the evidence provided by the PEGASUS study and whether the medical community believes duration of DAPT also to be dependent on type of $\mathrm{P} 2 \mathrm{Y}_{12}$ inhibitor is in preparation.

\section{Conclusions}

This EAPCI survey highlights considerable uncertainty within the medical community with regard to the optimal duration of DAPT after coronary stenting in the light of recently reported trial results. The medical community surveyed called for new evidence or updated guidance on how DAPT duration should be individualised for each patient.

\section{Impact on daily practice}

Against the conduct of ten dedicated randomised studies investigating various durations of dual antiplatelet therapy (DAPT) and the recent publication of the DAPT trial, which enrolled almost 9,500 patients, the optimal duration of dual antiplatelet therapy after coronary stenting remains unclear. This survey highlights uncertainties within the medical community with regard to how DAPT duration should be managed in clinical practice. A joint effort of international societies, leveraging on the contribution of each principal investigator of the available trials to provide outcomes in pre-specified patient subsets, or ideally the performance of an individual patient meta-analysis, may clarify the most suited DAPT duration for each single patient in practice in future. Providing guidance to the clinical community with respect to the individualisation of the antiplatelet therapy based on patients ischaemic and bleeding risk will be crucial to optimise benefits versus risks.

\section{Acknowledgements}

The authors would like to express their gratitude to the staff of Europa Organisation/EuroPCR for the support given during survey planning and conduct.

\section{Conflict of interest statement}

The authors have no conflicts of interest to declare.

\section{References}

1. Schömig A, Neumann FJ, Kastrati A, Schuhlen H, Blasini R, Hadamitzky M, Walter H, Zitzmann-Roth EM, Richardt G, Alt E, Schmitt C, Ulm K. A randomized comparison of antiplatelet and anticoagulant therapy after the placement of coronary-artery stents. N Engl J Med. 1996;334:1084-9. 
2. Mehta SR, Yusuf S, Peters RJ, Bertrand ME, Lewis BS, Natarajan MK, Malmberg K, Rupprecht H, Zhao F, Chrolavicius S, Copland I, Fox KA; Clopidogrel in Unstable angina to prevent Recurrent Events trial (CURE) Investigators. Effects of pretreatment with clopidogrel and aspirin followed by long-term therapy in patients undergoing percutaneous coronary intervention: the PCICURE study. Lancet. 2001;358:527-33.

3. Windecker S, Kolh P, Alfonso F, Collet JP, Cremer J, Falk V, Filippatos G, Hamm C, Head SJ, Jüni P, Kappetein AP, Kastrati A, Knuuti J, Landmesser U, Laufer G, Neumann FJ, Richter DJ, Schauerte P, Sousa Uva M, Stefanini GG, Taggart DP, Torracca L, Valgimigli M, Wijns W, Witkowski A. 2014 ESC/EACTS Guidelines on myocardial revascularization. EuroIntervention. 2015;10:1024-94.

4. Levine GN, Bates ER, Blankenship JC, Bailey SR, Bittl JA, Cercek B, Chambers CE, Ellis SG, Guyton RA, Hollenberg SM, Khot UN, Lange RA, Mauri L, Mehran R, Moussa ID, Mukherjee D, Nallamothu BK, Ting HH. 2011 ACCF/AHA/SCAI Guideline for Percutaneous Coronary Intervention: a report of the American College of Cardiology Foundation/American Heart Association Task Force on Practice Guidelines and the Society for Cardiovascular Angiography and Interventions. Circulation. 2011;124:e574-651.

5. Valgimigli M, Park SJ, Kim HS, Park KW, Park DW, Tricoci P, Ferrante G. Benefits and risks of long-term duration of dual antiplatelet therapy after drug-eluting stenting: a meta-analysis of randomized trials. Int J Cardiol. 2013;168:2579-87.

6. Valgimigli M, Ariotti S, Costa F. Duration of dual antiplatelet therapy after drug-eluting stent implantation: will we ever reach a consensus? Eur Heart J. 2015 Mar 11. [Epub ahead of print].

7. Mauri L, Kereiakes DJ, Yeh RW, Driscoll-Shempp P, Cutlip DE, Steg PG, Normand SL, Braunwald E, Wiviott SD, Cohen DJ, Holmes DR Jr, Krucoff MW, Hermiller J, Dauerman HL, Simon DI, Kandzari DE, Garratt KN, Lee DP, Pow TK, Ver Lee P, Rinaldi MJ, Massaro JM. DAPT Study Investigators. Twelve or 30 months of dual antiplatelet therapy after drug-eluting stents. $N$ Engl J Med. 2014;371:2155-66.

8. Schulz-Schupke S, Byrne RA, Ten Berg JM, Neumann FJ, Han Y, Adriaenssens T, Tolg R, Seyfarth M, Maeng M, Zrenner B,
Jacobshagen C, Mudra H, von Hodenberg E, Wohrle J, Angiolillo DJ, von Merzljak B, Rifatov N, Kufner S, Morath T, Feuchtenberger A, Ibrahim T, Janssen PW, Valina C, Li Y, Desmet W, Abdel-Wahab M, Tiroch K, Hengstenberg C, Bernlochner I, Fischer M, Schunkert H, Laugwitz KL, Schomig A, Mehilli J, Kastrati A; on behalf of the Intracoronary Stenting and Antithrombotic Regimen: Safety And EFficacy of 6 Months Dual Antiplatelet Therapy After DrugEluting Stenting (ISAR-SAFE) trial investigators. ISAR-SAFE: a randomized, double-blind, placebo-controlled trial of 6 versus 12 months of clopidogrel therapy after drug-eluting stenting. Eur Heart J. 2015 Jan 23. [Epub ahead of print].

9. Gilard M, Barragan P, Noryani AA, Noor HA, Majwal T, Hovasse T, Castellant P, Schneeberger M, Maillard L, Bressolette E, Wojcik J, Delarche N, Blanchard D, Jouve B, Ormezzano O, Paganelli F, Levy G, Sainsous J, Carrie D, Furber A, Berland J, Darremont O, Le Breton H, Lyuycx-Bore A, Gommeaux A, Cassat C, Kermarrec A, Cazaux P, Druelles P, Dauphin R, Armengaud J, Dupouy P, Champagnac D, Ohlmann P, Endresen K, Benamer H, Kiss RG, Ungi I, Boschat J, Morice MC. 6- versus 24-month dual antiplatelet therapy after implantation of drug-eluting stents in patients nonresistant to aspirin: the randomized, multicenter ITALIC Trial. J Am Coll Cardiol. 2015;65:777-86.

10. Bonaca MP, Bhatt DL, Cohen M, Steg PG, Storey RF, Jensen EC, Magnani G, Bansilal S, Fish MP, Im K, Bengtsson O, Ophuis TO, Budaj A, Theroux P, Ruda M, Hamm C, Goto S, Spinar J, Nicolau JC, Kiss RG, Murphy SA, Wiviott SD, Held P, Braunwald E, Sabatine MS; PEGASUS-TIMI 54 Steering Committee and Investigators. Long-Term Use of Ticagrelor in Patients with Prior Myocardial Infarction. N Engl J Med. 2015 Mar 14. [Epub ahead of print].

\section{Online data supplement}

Online Appendix. List of respondents.

Online Table 1. Declared clinical practice of respondents concerning DAPT duration before AHA 2014.

Online Table 2. Declared clinical practice of respondents concerning DAPT duration after AHA 2014.

Online Figure 1. Geographic region of practice of the respondents. 


\section{Online data supplement}

\section{Appendix List of respondents FIRST PART OF THE SURVEY}

Aaroe J., Denmark

Aasa M., Sweden

Abdel-Salam A.M., Egypt

Abdulwahab H., Kuwait

Accardi R., Italy

Adel A., Belgium

Al Mowafy A., Kuwait

Al-Najjar Y., United Kingdom

Alaarag A.F., Egypt

Aladashvili A., Georgia

Alawfi K., France

Alcazar De La Torre E., Mexico

Alejos R., Mexico

Alfonso Jimenez V., Spain

Alhashimi H.M.M., Netherlands

Aljeboury A., Iraq

Almeida De Sousa J., Brazil

Almusawi A., Iraq

Alshaikha M., Egypt

Altaf S., Pakistan

Altahmody K.E.A., Egypt

Alvarez Contreras L.R., Mexico

Amarasena N., Sri Lanka

Amoroso G., Netherlands

Anderson R., United Kingdom

Andò G., Italy

Andrade J., Spain

Andreou A.Y., Cyprus

Angulo J., Mexico

Antonio T., Italy

Aprigliano G., Italy

Aquilina M., Italy

Arafa S.E.O., Qatar

Aramberry L., Argentina

Arampatzis C.A., Greece

Araujo J. J., Portugal

Asher E., Israel

Ates I., Turkey

Athanasias D., Greece

Auer J., Austria

Auffret V., France

Ayala F.J., Chile

Baba C., Romania

Baglioni P., Argentina

Bagur R., Canada

Balam-Ortiz E, Mexico

Balducelli M, Italy

Bam Pas G, Greece

Barbash I.M., Israel
Barbosa A. H. P., Brazil

Barbosa R., Brazil

Barnay P., France

Barroso L., Brazil

Basti A., Switzerland

Bax M., Netherlands

Bayet G., France

Beijk M.A., Netherlands

Beltran R., Venezuela

Berenguer Jofresa A., Spain

Berroth R., Germany

Berti S., Italy

Berumen Dominguez L.E., Mexico

Bhasin A., India

Bhaya M., Mauritius

Bianco M., Italy

Biasco L., Denmark

Bikicki M., Serbia

Bonarjee V.V.S., Norway

Bonechi F, Italy

Borges Santos M., Portugal

Boshev M., Macedonia

Bouferrouk A, Algeria

Bounartzidi M., Greece

Bousoula E., Greece

Brie D., Romania

Brtko M., Czech Republic

Brugaletta S., Spain

Brull D.J., United Kingdom

Buchter B, Germany

Buendia R., Philippines

Burzotta F., Italy

Butz T., Germany

Buzzetti F., Italy

Bychowiec B., Poland

Cadeddu M., Italy

Campanile A., Italy

Carneiro J.G., Brazil

Carrilho-Ferreira P., Portugal

Carrillo Guevara J.E., Mexico

Carter A.J., United States

Casal-Heredia H., Venezuela

Castiglioni B., Italy

Castro Fabiano L., Brazil

Cavalcante Silva R., Brazil

Cavalcanti De Oliveira D., Brazil

Cavalcanti R.C., Brazil

Cavazza C., Italy

Centemero M.P., Brazil
Chabane H.K., Italy

Chamié D., Brazil

Chatzis D., Greece

Chaves A.J., Brazil

Cheng S., China

Chinchilla H., Honduras

Ciabatti N., Italy

Cirillo P., Italy

Çitaku H., Albania

Claeys M.J., Belgium

Clifford Cp, United Kingdom

Coceani M., Italy

Cóggiola J., Argentina

Cohen D.J., United States

Conway D.S.G., United Kingdom

Cornelis K., Belgium

Coroleu S. F., Argentina

Corral J.M., Colombia

Cortese B., Italy

Coskun U., Turkey

Costa F., Italy

Costa R.A., Brazil

Coste P., France

Coufal Z., Czech Republic

Cox S., Australia

Cozma A., Romania

Crean P., Ireland

Crenshaw M.H., United States

Cristian U., Romania

Cruz-Alvarado J.E., Mexico

Cuculi F., Switzerland

Cuenza L., Philippines

Cyrne Carvalho H., Portugal

D'Ascenzo F., Italy

D'Urbano M., Italy

Damonte A., Argentina

Dan Florin F, Romania

Dana A., United Kingdom

Dangoisse V, Belgium

De Backer O., Denmark

De Cock D., Belgium

De Vita M., Italy

Debski A., Poland

Delgado A., Mexico

Devadathan S., United Kingdom

Dhamrait S., United Kingdom

Di Lorenzo E., Italy

Di Serafino D., Italy

Diego-Nieto A., Spain 
Dievart F., France

Diez J.L., Spain

Dimitriadis K., Greece

Dina C., Romania

Doerner O., Germany

Donahue M., Italy

Donis J., Venezuela

Drieghe B., Belgium

Drissi M.F., Tunisia

Du Fretay H., France

Dziewierz A., Poland

Echavarría-Pinto M., Spain

Echeverria Romero R.G., Honduras

Economou F., Greece

Eftychiou C., Cyprus

Egdell R., United Kingdom

El Hosieny A., Saudi Arabia

El Meguid K., Egypt

Elabbassi W., United Arab Emirates

Elesgerli S., Azerbaijan

Elghetany H., Saudi Arabia

Elizondo J.C., Costa Rica

Elkahlout A., Romania

Elrowiny R., Egypt

Elserafy A.S., Egypt

Emam A., Egypt

Emara A., Egypt

Emmanouil P., Greece

Ercilla J., Peru

Erglis A., Latvia

Eslam Taha E., Egypt

Esmaeil S., Egypt

Esposito G., Italy

Ettori F., Italy

Eugenio N., Brazil

Everaert B., Netherlands

Ezquerra Aguilar W., Peru

Falu R., Argentina

Farag E., Egypt

Farjalla J., Brazil

Feldman L., France

Feldman M., Argentina

Felice H., Malta

Fernandez-Nofrerias E., Spain

Fernández-Rodríguez D., Spain

Ferranti F., Italy

Ferreira Q., Qatar

Ferrone M., Italy

Fleischmann C., Germany

Flessas D., Greece

Formigli D., Italy

Fozilov H., Uzbekistan

Fraccaro C., Italy

Freitas J.O., Brazil

Fresco C., Italy
Fridrich V., Slovakia

Furmaniuk J., Poland

Gagnor A., Italy

Galasso G., Italy

Galeazzi G.L., Italy

Galli S., Italy

Galvez Villacorta V., Peru

Gandolfo C., Italy

García E., Spain

García-Blas S., Spain

Garducci S., Italy

Garg S., United Kingdom

Garro N., Italy

Gatto L., Italy

Georgiou M.G., Cyprus

Ghanem I., Egypt

Ghose T., India

Giacchi G., Italy

Giang P.T., Viet Nam

Giesler T., Germany

Giovino M., Italy

Girardi P., Italy

Girasis C., Greece

Giunio L., Croatia

Giustino G., United States

Glatthor C., Germany

Glogar H.D., Austria

Golledge P., United Kingdom

Gomez Moreno J., Argentina

Gómez Recio M., Spain

Gommeaux A., France

Grantalis G., Greece

Greco F., Italy

Grundeken M.J., Netherlands

Grunert S., Germany

Guðmundsdóttir I., Iceland

Guenoun M., France

Guerios E., Brazil

Gupta R., United Arab Emirates

Gupta S., India

Gutièrrez C., Mexico

Hafeez I., India

Halvorsen S., Norway

Hamed Hussein G.A., Saudi Arabia

Hammoudeh A., Jordan

Hansen P.R., Denmark

Harb S., Austria

Hawas J.M., Iraq

Hayrapetyan H., Armenia

Heintzen M.P., Germany

Hengstenberg C., Germany

Herity N., United Kingdom

Hernandez F., Spain

Heyse A., Belgium

Hicham D., Lebanon
Hildick-Smith D., United Kingdom

Hill J., United Kingdom

Hillani A., France

Hiltrop N., Belgium

Hiramori A., Japan

Hobson A.R., United Kingdom

Homan D.J., United States

Hooda A., India

Ielasi A., Italy

Ierna S., Italy

Iftikhar A.K., Pakistan

Ilic I., Serbia

Imai Y., Japan

Imperadore F., Italy

Indolfi C., Italy

Iorga V., Romania

Ipek E., Turkey

Ito S., Japan

Jacksch R., Germany

Jae-Sik J., South Korea

James S., Sweden

Jamshidi P., Switzerland

Jerbi J., Tunisia

Jimenez Quevedo P., Spain

Jimenez-Navarro M., Spain

Jiménez-Santos M., Mexico

Jin Q.H., China

Joksas V., Lithuania

Jovic D., Serbia

Junejo S., United Kingdom

Kallel R., Tunisia

Kamal A., Egypt

Kamiya H., Japan

Kannan D., India

Kantaria M., Georgia

Kapetanopoulos A., Greece

Kara Ali B., Lebanon

Karjalainen P.P., Finland

Karthikeyan V.J., United Kingdom

Kato R., Japan

Katsikis A., Greece

Kefer J., Belgium

Keta D., Germany

Ketteler T., Germany

Khan M., United Kingdom

Kharlamov A., Russian Federation

Kinani A., Iraq

Kinani T., Iraq

Kinnaird T., United Kingdom

Kislo A., Poland

Kiviniemi T., Finland

Kleiban A., Argentina

Kluck B., United States

Kocayigit I., Turkey

Kokis A., Canada 
Komiyama N., Japan

Konstantinos L., Greece

Kordalis A., Greece

Kozak M., United States

Krecki R., Poland

Kristensen S.D., Denmark

Krizanic F., Germany

Krsticevic L., Argentina

Kuex H., Germany

Kukreja N., United Kingdom

Kulić M., Bosnia and Herzegovina

Kulikovskikh Y.V., Russian Federation

Kulkarni P., India

Kumar N., Netherlands

Kumar Soni A., India

Kuzmenko E., Russian Federation

L'Allier P.L., Canada

Langner O., Germany

Lapin O., Russian Federation

Lauer B., Germany

Leclercq F., France

Leibundgut G., Switzerland

León Aliz E., Cuba

Leon C., Venezuela

Leon K., Egypt

Leoncini M., Italy

Leone A.M., Italy

Leroux L., France

Lesiak M., Poland

Letilovic T., Croatia

Lev E., Israel

Linares Vicente J.A., Spain

Lindsay S., United Kingdom

Loh P.H., Singapore

Loncar G., Serbia

Loo B., Ireland

Lopez M.B., Mexico

Lopez-Cuellar J., Mexico

Lozano I., Spain

Luigia P., Italy

Lunde K., Norway

Lyczywek M., Poland

Macdougall D., United Kingdom

Mafrici A., Italy

Magni V., Italy

Magro M., Netherlands

Mainar V., Spain

Makarović Z., Croatia

Malik N., United Kingdom

Maly M., Czech Republic

Mansour S., Canada

Marenco R.E., Honduras

Maresta A., Italy

Marinho G.E., Brazil

Marino R.L., Brazil
Marinucci L., Italy

Martins H., Brazil

Martins J., United Kingdom

Mashayekhi K., Germany

Masood A., Pakistan

Maurer E., Austria

Mavrogianni A.D., Greece

Mazurek T., Poland

Medina A., Mexico

Mehilli J., Germany

Mellwig K.P., Germany

Mendez M., Chile

Mendiz O.A., Argentina

Meneses A., Mexico

Mercado L.A., Bolivia

Mereuta A., Romania

Mezzapelle G., Italy

Milanovic N., Bosnia and Herzegovina

Mohamed S.M., Egypt

Mohanad A., Egypt

Mohanty A., India

Moorthy N., India

Morales F.J., Spain

More R., United Kingdom

Moreno Samos J.C., Spain

Moreno-Martínez F.L., Spain

Moscato F., Italy

Mossmann M., Brazil

Mrevlje B., Germany

Müller-Eichelberg A., Germany

Muraglia S., Italy

Musumeci G., Italy

Nadir Khan M., Pakistan

Najim S., United Kingdom

Nakamura S., Japan

Nakao F., Japan

Näveri H., Finland

Negus B., United States

Nerla R., Italy

Nguyen H.T., United States

Niess G.S., United States

Nikas D.N., Greece

Niroomand F., Germany

Niva J., Finland

Nogueira J.W., Brazil

Nombela-Franco L., Spain

Notrica M., Argentina

Nouri B., Tunisia

Nugue O., France

Nunes G.L., Brazil

Ober M., Romania

Ochoa J., Colombia

Oh J.H., South Korea

Ojeda S., Spain

Oktay Tureli H., Turkey
Olowe Y., United States

Oluseun A., United States

Opolski G., Poland

Ornelas C.E., Brazil

Otasevic P., Serbia

Ozturk A., Turkey

Padilla F., Mexico

Pagny J.Y., France

Paolantonio D., Argentina

Papaioannou G.I., Greece

Parodi G., Italy

Patil S.N., India

Pavei A., Italy

Pavìa A., Mexico

Pavlidis A., United Kingdom

Pell A., United Kingdom

Percoco G.F., Italy

Pernasetti L.V., Spain

Pescoller F., Italy

Petropoulakis P., Greece

Piatti L., Italy

Picardi E., Italy

Pieroni D.M., Argentina

Pina J., United States

Pinheiro L.F., Brazil

Pinto F.J., Portugal

Pipa J.L., Portugal

Piroth Z., Hungary

Pisano F., Italy

Podbregar M., Slovenia

Polak G., Poland

Polimeni A., Italy

Postadzhiyan A., Bulgaria

Postu M., Romania

Poulimenos L.E., Greece

Pow Chon Long F., Ecuador

Poyet R., France

Pradhan Ak, India

Predescu L.M., Romania

Prida X.E., United States

Prof. Aly Saad, Egypt

Prog R., Germany

Pulikal D.G.A, United Kingdom

Qiangzhong P.I., China

Radu M.D., Denmark

Rajendran D., India

Ram Anil Raj M.R., India

Ramazzotti V., Italy

Rapacciuolo A., Italy

Ratib K., United Kingdom

Raungaard B., Denmark

Raviola E., Italy

Reppas E., Greece

Reyes J.A., Dominican Republic

Rezek M., Czech Republic 
Riess G.J., Germany

Rifaie O., Egypt

Rigattieri S., Italy

Rissanen T., Finland

Ristic A.D., Serbia

Rittger H., Germany

Roberts J., United States

Rodríguez Saavedra A., Argentina

Roik M., Poland

Roshan Rao K, India

Routledge H., United Kingdom

Rubboli A., Italy

Rudolph T., Germany

Rudzitis A., Latvia

Ruiters Aw, Netherlands

Ruiz Ros J.A., Spain

Ruiz-García J., Spain

Ruiz-Nodar J.M., Spain

Sabate M., Spain

Sabnis G., India

Sabouret P., France

Sacra C., Italy

Saghatelyan M., Armenia

Sahin M., Turkey

Said S., Netherlands

Salachas A., Greece

Salas Llamas J.P., Mexico

Salih A., Saudi Arabia

Sanchez O.D., United States

Sánchez-Gila J., Spain

Sanchez-Perez I., Spain

Santarelli A., Italy

Sardovski, Bulgaria

Sarenac D., Serbia

Sarma J., United Kingdom

Sarno G., Sweden

Savonitto S., Italy

Sayied Abdullah A., Ireland

Schäfer A., Germany

Scherillo M., Italy

Schneider H., Germany

Schühlen H., Germany

Sciahbasi A., Italy

Seca L., Portugal

Sedlon P., Czech Republic

Semenka J., Czech Republic

Serra L.A., Spain

Sesana M., Italy

Sethi A., United Kingdom

Sgueglia G.A., Italy

Shaheen S., Egypt
Shahri H., Iran

Sheiban I., Italy

Shyu K.G., Taiwan

Silva C.E., Brazil

Sionis D., Greece

Siqueira D.A., Brazil

Siqueira M.J., Brazil

Smits P., Netherlands

Sobhy M., Egypt

Sokolov M., Ukraine

Soliman S., Egypt

Somani A.N., India

Sridhar G., Malaysia

Stakos D., Greece

Št'ásek J., Czech Republic

Stefanini G., Switzerland

Steigen T.K., Norway

Stewart, New Zealand

Stipal R., Czech Republic

Stochino M.L., Italy

Stoel M.G., Netherlands

Stoyanov N., Bulgaria

Subla R.M., United States

Suliman A., Sudan

Summaria F., Italy

Syarif R., Indonesia

Syed A.A., United States

Tanaka Y., Japan

Tashani A., Libya

Tauzin S., France

Tawade N., India

Tawfik M., Egypt

Tayeh O., Egypt

Terzic I., Bosnia Herzegovina

Testa L., Italy

Thevan B., Bahrain

Thiam M., Senegal

Tiecco F., Italy

Tierala I., Finland

Tilea I., Romania

Tilsted H. H., Denmark

Tomasik A.R., Poland

Tonev I., Bulgaria

Torres Bosco A., Spain

Tousek P., Czech Republic

Townend J., United Kingdom

Tran Ngoc T., Viet Nam

Triantafyllou K., Greece

Tsigkas G., Greece

Tsioufis C., Greece

Turri M., Italy
Tyligadis G., Greece

Ugo F., Italy

Ultramari F.T., Brazil

Urban P., Switzerland

Uren N., United Kingdom

Uretsky B.F., United States

Uribe C.E., Colombia

Usman B., Kazakhstan

Valadez Molina F., Mexico

Van Houwelingen K.G., Netherlands

Vandormael M., United States

Varvarovsky I., Czech Republic

Vassilis V., Greece

Velasquez D., Colombia

Verdoia M., Italy

Vermeersch P., Belgium

Vidal-Perez R., Spain

Vinesh J., India

Violini R., Italy

Vista J.H., Mexico

Vogt F., Germany

Vogt M., Germany

Vokac D., Slovenia

Vom Dahl J., Germany

Vranckx P., Belgium

Wahab A., India

Wang R., Brazil

Wang T.D., Taiwan

Wani S., India

Weisz S.H., Italy

Werner G.S., Germany

Wilkinson J.R., United Kingdom

Wolf A., Germany

Youssef A., Egypt

Yumoto K., Japan

Zaderenko N., Argentina

Zaghloul Darwish A., Egypt

Zahn R., Germany

Zaro T., Italy

Zavalloni D., Italy

Zbinden R., Switzerland

Zekanovic D., Croatia

Zhang B., China

Zhang C., China

Zhang Y.J., China

Zhonghan N., China

Zingarelli A., Italy

Zueco J., Spain

Zuhairy H., Ireland 


\section{SECOND PART OF THE SURVEY}

Aaroe J., Denmark

Abbate A., United States

Abdel Hamid M., Egypt

Abdelmegid M.A.F., Egypt

Acuña-Valerio J., Mexico

Adriaenssens T., Belgium

Agostoni P., Netherlands

Aikot H., India

Alameda M., Spain

Alcaraz H., Mexico

Almendro-Delia M., Spain

Altug Cakmak H., Turkey

Amir A., United Kingdom

Amoroso G., Netherlands

Andò G., Italy

Andrade J., Spain

Arampatzis C.A., Greece

Arjomand A., Australia

Assomull R., United Kingdom

Atalar E., Turkey

Auer J., Austria

Auffret V., France

Avramides D., Greece

Aytek Şimşek M., Turkey

Aznaouridis K., United Kingdom

Azpeitia Y., Mexico

Baglioni P., Spain

Barnabas C., South Africa

Barsness G.W., United States

Bartorelli A.L., Italy

Basoglu A., Belgium

Bayet G., France

Benezet J., Spain

Benincasa S., Italy

Berland J., France

Berrocal D.H., Argentina

Berroth R., Germany

Bett N., Australia

Bhaya M., Mauritius

Bianco M., Italy

Boskovic S., Serbia

Brandão V., Portugal

Brtko M., Czech Republic

Brull D.J., United Kingdom

Buchter B., Germany

Caporale R., Italy

Caprotta F., Argentina

Carrabba N., Italy

Carrilho-Ferreira P., Portugal

Casal-Heredia H., Venezuela

Cazaux P., France

Chaves A.J., Brazil

Cheniti G., Tunisia

Chinchilla Calix H., Honduras

Chung W.Y., South Korea

Cicco N., Germany
Cicco N.A., Germany

Cieza T., Canada

Clapp B., United Kingdom

Coceani M., Italy

Commeau P., France

Conway D., United Kingdom

Cortese B., Italy

Cuellar C., Colombia

D'Urbano M., Italy

Damonte A., Argentina

De Backer O., Denmark

De Benedictis M., Italy

De La Torre Hernandez J.M., Spain

De Vroey F., Belgium

Degertekin M., Turkey

Di Lorenzo E., Italy

Diez J.L., Spain

Dina C., Romania

Eberli F.R., Switzerland

Echavarria-Pinto M., Spain

Eggebrecht H., Germany

Ekicibasi E., Turkey

Elmaraghi M., Egypt

Előd P., Hungary

Ercilla J., Peru

Ergene A.O., Turkey

Ezquerra Aguilar W., Peru

Fadlalla V.F., Egypt

Farah M.A., Argentina

Fernandez Viña R., Argentina

Fernández-Rodríguez D., Spain

Ferro A., Italy

Fischer D., Germany

Floré V., Belgium

Foley D.P., Ireland

Formigli D., Italy

Fresco C., Italy

Furmaniuk J., Poland

Gafoor S., Germany

Gallo S., Paraguay

Garg S., United Kingdom

Gaspardone A., Italy

Gavrilescu D., Romania

Gentiletti A., Argentina

Giacchi G., Spain

Gilard M., France

Giovannelli F., Italy

Glogar H.D., Austria

Gomez Moreno J.O., Argentina

Gomez Recio M., Spain

Gommeaux A., France

Gonzalez Pacheco I., Mexico

Gonzalo N., Spain

Grajek S., Poland

Greco F., Italy

Gurgel De Medeiros J.P., Brazil
Haine S., Belgium

Hakim D., United States

Hakim Vista J.J., Mexico

Hallani H., Australia

Hamid M., Sweden

Hansen P.R., Denmark

Heintzen M.P., Germany

Helft G., France

Heppell R.M., United Kingdom

Hernández-Enríquez M., Spain

Hlinomaz O., Czech Republic

Ho Choo E., South Korea

Huqi A., Italy

Hurtado E.O., Colombia

Iakovou I., Greece

Ielasi A., Italy

Imperadore F., Italy

Iosseliani D., Russian Federation

Ipek E., Turkey

Jacksch R., Germany

Janssens L., Belgium

Jean M., France

Jensen J.K., Denmark

Jensen, J., Sweden

Jesudason P., Malaysia

Jimenez Diaz V.A., Spain

Karchevsky D., Russian Federation

Karpovskii A., Russian Federation

Katsimagklis G., Greece

Kereiakes D., United States

Kersanova N.C., Chile

Kesavan S., United Kingdom

Ketteler T., Germany

Khaled H., Egypt

Khalil S.A, Morocco

Khan M., United Kingdom

Kharlamov A., Russian Federation

Kiatchoosakun S., Thailand

Kim K.S., South Korea

Kinnaird T., United Kingdom

Kirma C., Turkey

Kleiban A., Argentina

Koltowski L., Poland

Konteva M., Bulgaria

Kozinski L., Poland

Kuehn C.R., Germany

Kukreja N., United Kingdom

Kulić M., Bosnia and Herzegovina

Kumar S., United States

Kyriakakis C.G., South Africa

Laanmets P., Estonia

Labrunie A., Brazil

Ladwiniec A., United Kingdom

Lai G., Italy

Laine M., France

Latib A., Italy 
Lattuca B., France

Lauer B., Germany

Lazarevic A.M., Bosnia and Herzegovina

Lee K.S., United States

Legrand V., Belgium

Leiva G., Argentina

Leoncini M., Italy

Leoncini M., Italy

Lester N., South Africa

Letilovic T., Croatia

Levchyshyna O., Ukraine

Linares Vicente J.A., Spain

Livia G., Spain

Londero H.F., Argentina

Luha O., Austria

Lunde K., Norway

Lupi A., Italy

Lupkovics G., Hungary

Maaliki S., United States

Macdougall D., United Kingdom

Maeng M., Denmark

Mahr N.C., United States

Mansour S., Canada

Mantyla P., Finland

Mariano E., Italy

Marsit N., Tunisia

Martins H.C., Brazil

Mcdonough T.J., United States

Medda M., Italy

Mejia Viana S., Spain

Mendiz O.A., Argentina

Merigo Azpir C.A., Mexico

Mezzapelle G., Italy

Milanovic N., Bosnia and Herzegovina

Mitreski S., Macedonia

More R., United Kingdom

Moreno R., Spain

Moreu J., Spain

Moscato F., Italy

Muehler M., Germany

Muir D., United Kingdom

Munoz Molina R., Guatemala

Musilli N., Italy

Myć J., Poland

Nadra I., Canada

Nagy C.D., United States

Narayanan A., United States

Neugebauer P., Slovakia

Nguyen M, Canada

Nick H., Belgium

Nicolino A., Italy

Obradovic S.D., Serbia

Padilla F., Mexico

Paizis I., Greece

Panagiotis P., Greece

Park S.D., South Korea

Park S.J., South Korea
Pasquetto G., Italy

Patel D., United Kingdom

Paunovic D., Belgium

Pavìa A., Mexico

Pedon L., Italy

Pereira Machado F., Portugal

Pershukov H., Russian Federation

Petrou E., Greece

Piatti L., Italy

Pinheiro L.F., Brazil

Pinton F.A., Brazil

Pisano F., Italy

Polak G., Poland

Poyet R., France

Preti G., Italy

Prog R., Germany

Puri R., Canada

Pyxaras S.A., Germany

Quintanilla J., Mexico

Ramazzotti V., Italy

Raviola E., Italy

Rhouati A., Algeria

Ribeiro De Oliveira I., Brazil

Rigattieri S., Italy

Rissanen T., Finland

Rivetti L., Italy

Rodriguez A.E., Argentina

Rotevatn S., Norway

Routledge H., United Kingdom

Rubartelli P., Italy

Rubboli A., Italy

Ruiz-García J., Spain

Saad A., Egypt

Sabate M., Spain

Sabouret P., France

Sachdeva R., United States

Said S., Netherlands

Salachas A.J., Greece

Sanchez-Perez H., Spain

Sangiorgi G., Italy

Santarelli A., Italy

Santoro G.M., Italy

Saporito F., Italy

Sarenac D., Serbia

Savonitto S., Italy

Scappaticci M., Italy

Schmermund A., Germany

Schmidt J.E., United States

Schmitz T., Germany

Schneider H., Germany

Schneider T.I., Germany

Schuchlenz H., Austria

Schühlen H., Germany

Sepúlveda Varela P., Chile

Sesana M., Italy

Sethi A., United Kingdom

Shaw E., Australia
Silva C.E.F., Brazil

Silva Marques J., Portugal

Sionis D., Greece

Skalidis E., Greece

Slhessarenko J., Brazil

Spauldingc., France

Stakos D., Greece

Stankovic G., Serbia

Stasek J., Czech Republic

Stefanini G.G., Italy

Suwannasom P., Thailand

Synetos A., Greece

Szuster E., Brazil

Taha S., Egypt

Tavano D., Italy

Tebet M., Brazil

Thury A., Hungary

Tilsted H.H., Denmark

Tomasik A., Poland

Toutouzas K., Greece

Triantafyllis A.S., Greece

Tsikaderis D., Greece

Tumscitz C., Italy

Turri M., Italy

Tyligadis G., Greece

Tzanogiorgis I., Greece

Udovichenko A., Russian Federation

Ulrike N., Austria

Unikas R., Lithuania

Uren N., United Kingdom

Uretsky B.F., United States

Valerio M.G., United States

Van Mieghem C., Belgium

Vandendriessche T., Belgium

Vavlukis M., Macedonia

Vidal-Perez R., Spain

Vigna C., Italy

Vilar J.V., Spain

Vizzari G., Italy

Vogt F., Germany

Voudris V., Greece

Wafa S., Egypt

Wagner D.R., Luxembourg

Webster M., New Zealand

Wichter T., Germany

Wiedemann S., Germany

Williams P.D., United Kingdom

Woody W., United States

Yding A., United Kingdom

Zachow G., Germany

Zaderenko N., Argentina

Zaghloul Darwish A.M., Egypt

Zbinden R., Switzerland

Zhang Y.J., China

Zingarelli A., Italy 
Online Table 1. Declared clinical practice of respondents concerning DAPT duration before AHA 2014.

\begin{tabular}{|c|c|c|}
\hline & $\begin{array}{c}\text { Response } \\
\text { percent }\end{array}$ & $\begin{array}{c}\text { Response } \\
\text { count }\end{array}$ \\
\hline \multicolumn{3}{|l|}{$\begin{array}{l}\text { For how long do you generally prescribe DAPT after DES implantation in patients not requiring oral anticoagulation? } \\
\text { (Answered question } 1,134 \text { - skipped question 0) }\end{array}$} \\
\hline For more than 12 months in all patients & $10.3 \%$ & 117 \\
\hline For 12 months in all patients & $53.2 \%$ & 603 \\
\hline For 6 months in all patients & $2.7 \%$ & 31 \\
\hline For 6 months in stable patients for 12 months in ACS patients & $23.5 \%$ & 267 \\
\hline It varies from patient to patient & $10.2 \%$ & 116 \\
\hline \multicolumn{3}{|c|}{$\begin{array}{l}\text { Do you weigh ischaemic and/or bleeding risk in prescribing DAPT duration to your patients not requiring oral anticoagulation? } \\
\text { (Answered question } 1,134 \text { - skipped question } 0 \text { ) }\end{array}$} \\
\hline No, never, I always prescribe a fixed DAPT duration upfront and try to stick to it in all my patients & $11.2 \%$ & 127 \\
\hline Yes, I take into consideration the ischaemic risk & $3.5 \%$ & 40 \\
\hline Yes, I take into consideration the bleeding risk & $11.1 \%$ & 126 \\
\hline Yes, I take into consideration both ischaemic and bleeding risk & $74.2 \%$ & 841 \\
\hline
\end{tabular}

Do you think that the occurrence of a minor actionable or non-actionable bleeding while on DAPT identifies patients at high risk for DAPT-related more relevant bleeding and as such should it trigger shortening of DAPT?

(Answered question 961 - skipped question 173)

No, I generally try to stick to the original DAPT prescription even if minor bleeds occur during the course of therapy

Yes, the occurrence of nuisance or minor bleeding while the patient is on DAPT is a predictor of future major bleeding events and I try to shorten DAPT duration as much as possible in these patients.

\begin{tabular}{|l|l|}
\hline $63.6 \%$ & 611 \\
\hline $36.4 \%$ & 350 \\
\hline
\end{tabular}

Do you think that the stent thrombosis risk is significantly lower with newer-generation stents as compared with early-generation DES?

(Answered question 961 - skipped question 173)

\begin{tabular}{|l|r|r|}
\hline Yes, first-generation DES require longer DAPT than newer-generation DES & 611 & 899 \\
\hline No, all DES are alike & $6.5 \%$ & 62 \\
\hline
\end{tabular}

Do you think that vulnerability to short DAPT duration varies from stent to stent within newer-generation stent platforms?

(Answered question 961 - skipped question 173)

Yes, I think duration of DAPT should strictly be stent-specific as thrombogenicity varies from stent to stent.

No, all newer-generation DES are alike

There is insufficient data to draw meaningful conclusions about this matter

\begin{tabular}{|l|l|}
\hline $30.5 \%$ & 293 \\
\hline $14.7 \%$ & 191 \\
\hline $54.8 \%$ & 527 \\
\hline
\end{tabular}

Provide your judgment regarding the safety profile (the safer the stent, the shorter DAPT can last after its implantation) of each of the following DES or vascular scaffolds when used in combination of a short ( 6 months or less) or very short ( 3 months or less) DAPT duration.

(Answered question 961 - skipped question 173)

Durable polymer newer-generation DES

Biodegradable polymer newer-generation DES

No polymer newer-generation DES

Bioresorbable everolimus-eluting Vascular Scaffold

\begin{tabular}{|l|r|r|}
\hline Safe with 3-month DAPT or less & $9.2 \%$ & 88 \\
\hline Safe with 6-month DAPT or less & $54.5 \%$ & 519 \\
\hline Insufficient data & $17.3 \%$ & 165 \\
\hline Not safe with short DAPT & $18.9 \%$ & 180 \\
\hline Safe with 3-month DAPT or less & $15.9 \%$ & 152 \\
\hline Safe with 6-month DAPT or less & $52.1 \%$ & 498 \\
\hline Insufficient data & $26.1 \%$ & 250 \\
\hline Not safe with short DAPT & $5.8 \%$ & 56 \\
\hline Safe with 3-month DAPT or less & $15.6 \%$ & 148 \\
\hline Safe with 6-month DAPT or less & $33.9 \%$ & 322 \\
\hline Insufficient data & $42.3 \%$ & 402 \\
\hline Not safe with short DAPT & $8.2 \%$ & 78 \\
\hline Safe with 3-month DAPT or less & $9.5 \%$ & 91 \\
\hline Safe with 6-month DAPT or less & $19.4 \%$ & 185 \\
\hline Insufficient data & $46.2 \%$ & 440 \\
\hline Not safe with short DAPT & $24.9 \%$ & 237 \\
\hline
\end{tabular}


Online Table 1. Declared clinical practice of respondents concerning DAPT duration before AHA 2014. (continued)

\begin{tabular}{|c|c|c|}
\hline & $\begin{array}{l}\text { Response } \\
\text { percent }\end{array}$ & $\begin{array}{l}\text { Response } \\
\text { count }\end{array}$ \\
\hline \multicolumn{3}{|l|}{$\begin{array}{l}\text { Do you think prolonged DAPT is beneficial for the prevention of ischaemic events, which are not stent-related? } \\
\text { (Answered question } 961 \text { - skipped question 173) }\end{array}$} \\
\hline Yes, DAPT protects from any coronary ischaemic both stent and not-stent related & $64.5 \%$ & 620 \\
\hline No, DAPT is only beneficial for the prevention of stent-related events & $35.5 \%$ & 341 \\
\hline \multicolumn{3}{|l|}{$\begin{array}{l}\text { How do you manage a patient who is at very high risk for bleeding requiring coronary stent implantation? } \\
\text { (Answered question } 946 \text { - skipped question 188) }\end{array}$} \\
\hline I preferentially implant a BMS and go for a 30-day DAPT regimen & $60.9 \%$ & 576 \\
\hline $\begin{array}{l}\text { I preferentially implant a newer-generation DES and go for 3-month DAPT and continue with aspirin } \\
\text { monotherapy }\end{array}$ & $18.8 \%$ & 178 \\
\hline $\begin{array}{l}\text { I preferentially implant a newer-generation DES and go for 6-month DAPT and continue with aspirin } \\
\text { monotherapy }\end{array}$ & $7.1 \%$ & 67 \\
\hline $\begin{array}{l}\text { I preferentially implant a newer-generation DES and go for 1-month DAPT and continue with } \mathrm{P}_{2} \mathrm{Y}_{12} \\
\text { inhibitor monotherapy }\end{array}$ & $5.8 \%$ & 55 \\
\hline $\begin{array}{l}\text { I preferentially implant a newer-generation DES and go for 1-month DAPT and continue with aspirin } \\
\text { monotherapy }\end{array}$ & $4.7 \%$ & 44 \\
\hline I preferentially implant a newer-generation DES and go for $\mathrm{P}_{2} \mathrm{Y}_{12}$ inhibitor monotherapy without aspirin & $2.7 \%$ & 26 \\
\hline \multicolumn{3}{|l|}{$\begin{array}{l}\text { What are your expectations regarding the DAPT trial, which will be presented at the upcoming AHA? } \\
\text { (Answered question } 908 \text { - skipped question 226) }\end{array}$} \\
\hline $\begin{array}{l}\text { This study will fail to show the superiority of 30-month DAPT regimen as compared to 12-month therapy } \\
\text { duration and I expect a clear excess of clinically significant bleeding liability. }\end{array}$ & $43.7 \%$ & 397 \\
\hline $\begin{array}{l}\text { This study will fail to show the superiority of 30-month DAPT regimen as compared to 12-month therapy } \\
\text { duration but I expect no or a clinically acceptable excess of bleeding }\end{array}$ & $28.9 \%$ & 262 \\
\hline $\begin{array}{l}\text { This study will show the superiority of 30-month DAPT regimen as compared to 12-month therapy } \\
\text { duration with a trade-off in bleeding }\end{array}$ & $17.6 \%$ & 160 \\
\hline $\begin{array}{l}\text { This study will show the superiority of 30-month DAPT regimen as compared to 12-month therapy } \\
\text { duration with no risk of bleeding }\end{array}$ & $9.8 \%$ & 89 \\
\hline \multicolumn{3}{|l|}{$\begin{array}{l}\text { What are your expectations regarding the ISAR-SAFE trial, which will be presented at the upcoming AHA? } \\
\text { (Answered question } 908 \text { - skipped question 226) }\end{array}$} \\
\hline $\begin{array}{l}\text { This study will show the non-inferiority of a 6-month DAPT duration versus } 12 \text {-month therapy with an } \\
\text { excess of bleeding in the 12-month therapy arm and no ischaemic risk in the } 6 \text {-month arm }\end{array}$ & $57.7 \%$ & 524 \\
\hline $\begin{array}{l}\text { This study will show the non-inferiority of a 6-month DAPT duration versus 12-month therapy with an } \\
\text { excess of bleeding in the 12-month therapy arm but a slight increase in the ischaemic risk in the } \\
6 \text {-month arm }\end{array}$ & $27.3 \%$ & 248 \\
\hline $\begin{array}{l}\text { This study will not show the non-inferiority of } 6 \text {-month DAPT duration versus } 12 \text {-month therapy due to } \\
\text { a frank ischaemic risk in the } 6 \text {-month DAPT arm which is not compensated by the bleeding events in the } \\
12 \text {-month arm. }\end{array}$ & $7.8 \%$ & 71 \\
\hline $\begin{array}{l}\text { This study will not show the non-inferiority of } 6 \text {-month DAPT duration versus } 12 \text {-month therapy due to } \\
\text { a frank ischaemic risk in the } 6 \text {-month DAPT arm and no bleeding difference as compared to } 12 \text {-month } \\
\text { therapy duration. }\end{array}$ & $7.2 \%$ & 65 \\
\hline
\end{tabular}


Online Table 2. Declared clinical practice of respondents concerning DAPT duration after AHA 2014.

\begin{tabular}{|l|r|r|}
\hline \multicolumn{1}{|l|}{$\begin{array}{c}\text { After the results of DAPT, ISAR SAFE and ITALIC/+, the duration of DAPT should (as compared to current practice/recommendations)? } \\
\text { (Answered question 432 - skipped question 110) }\end{array}$} & $\begin{array}{c}\text { Response } \\
\text { percent }\end{array}$ & \multicolumn{1}{c|}{$\begin{array}{c}\text { Response } \\
\text { count }\end{array}$} \\
\hline Be prolonged in all patients & $3.0 \%$ & 13 \\
\hline Be shortened in all patients & $3.7 \%$ & 16 \\
\hline Be prolonged in selected patients & $14.8 \%$ & 64 \\
\hline Be shortened in selected patients & $7.9 \%$ & 34 \\
\hline Be prolonged in selected patients AND be shortened in selected patients & $58.1 \%$ & 251 \\
\hline Unchanged & $12.5 \%$ & 54 \\
\hline
\end{tabular}

Which proportion of patients according to your interpretation of the data and your personal experience should be considered for DAPT duration well beyond one year?

(Answered question 432 - skipped question 110)

\begin{tabular}{|l|r|r|}
\hline None & $6.7 \%$ & 29 \\
\hline A limited proportion up to 10\% & $40.5 \%$ & 175 \\
\hline A limited proportion from 10\% to 30\% & $34.3 \%$ & 148 \\
\hline A proportion from 30\% to 50\% & $9.5 \%$ & 41 \\
\hline A proportion from 50\% to 70\% & $5.6 \%$ & 24 \\
\hline A proportion greater than 70\% & $3.5 \%$ & 15 \\
\hline
\end{tabular}

Should the guidelines change after DAPT, ISAR SAFE and ITALIC/+, with respect to duration of DAPT?

(Answered question 432 - skipped question 110)

No, they should not change

Yes, they should change

I do not know

\begin{tabular}{|r|r|}
\hline $39.4 \%$ & 170 \\
\hline $40.0 \%$ & 173 \\
\hline $20.6 \%$ & 89 \\
\hline
\end{tabular}

How should the guidelines change after DAPT, ISAR SAFE and ITALIC/+, with respect to duration of DAPT?

(Answered question 168 - skipped question 374)

\begin{tabular}{|c|c|c|}
\hline Guidelines should more proactively recommend a longer DAPT regimen than current recommendations & $12.5 \%$ & 21 \\
\hline Guidelines should more proactively recommend a shorter DAPT regimen than current recommendations & $15.5 \%$ & 26 \\
\hline $\begin{array}{l}\text { Guidelines should more proactively recommend a longer DAPT regimen than current recommendations in } \\
\text { selected patients AND a shorter DAPT regimen than current }\end{array}$ & $72.0 \%$ & 121 \\
\hline \multicolumn{3}{|l|}{$\begin{array}{l}\text { How do you think the field on DAPT duration should move forward? } \\
\text { (Multiple answers allowed) (Answered question } 419 \text { - skipped question 123) }\end{array}$} \\
\hline New randomised controlled trials with bigger sample size & $20.3 \%$ & 85 \\
\hline $\begin{array}{l}\text { New randomised controlled trials testing a truly individualised duration of therapy based on bleeding risk } \\
\text { at the time of inclusion }\end{array}$ & $17.2 \%$ & 72 \\
\hline $\begin{array}{l}\text { New randomised controlled trials testing a truly individualised duration of therapy based on ischaemic } \\
\text { risk at the time of inclusion }\end{array}$ & $13.4 \%$ & 56 \\
\hline $\begin{array}{l}\text { New randomised controlled trials testing a truly individualised duration of therapy based on bleeding } \\
\text { AND ischaemic risk at the time of inclusion }\end{array}$ & $54.7 \%$ & 229 \\
\hline $\begin{array}{l}\text { New randomised controlled trials testing the interruption of aspirin and the continuation of P2Y12 } \\
\text { inhibitor as compared to conventional DAPT }\end{array}$ & $35.6 \%$ & 149 \\
\hline $\begin{array}{l}\text { A consensus statement is needed which should provide guidance to physicians based on the evidence so } \\
\text { far generated }\end{array}$ & $34.8 \%$ & 146 \\
\hline I do not know & $3.6 \%$ & 15 \\
\hline Other & $2.6 \%$ & 11 \\
\hline
\end{tabular}




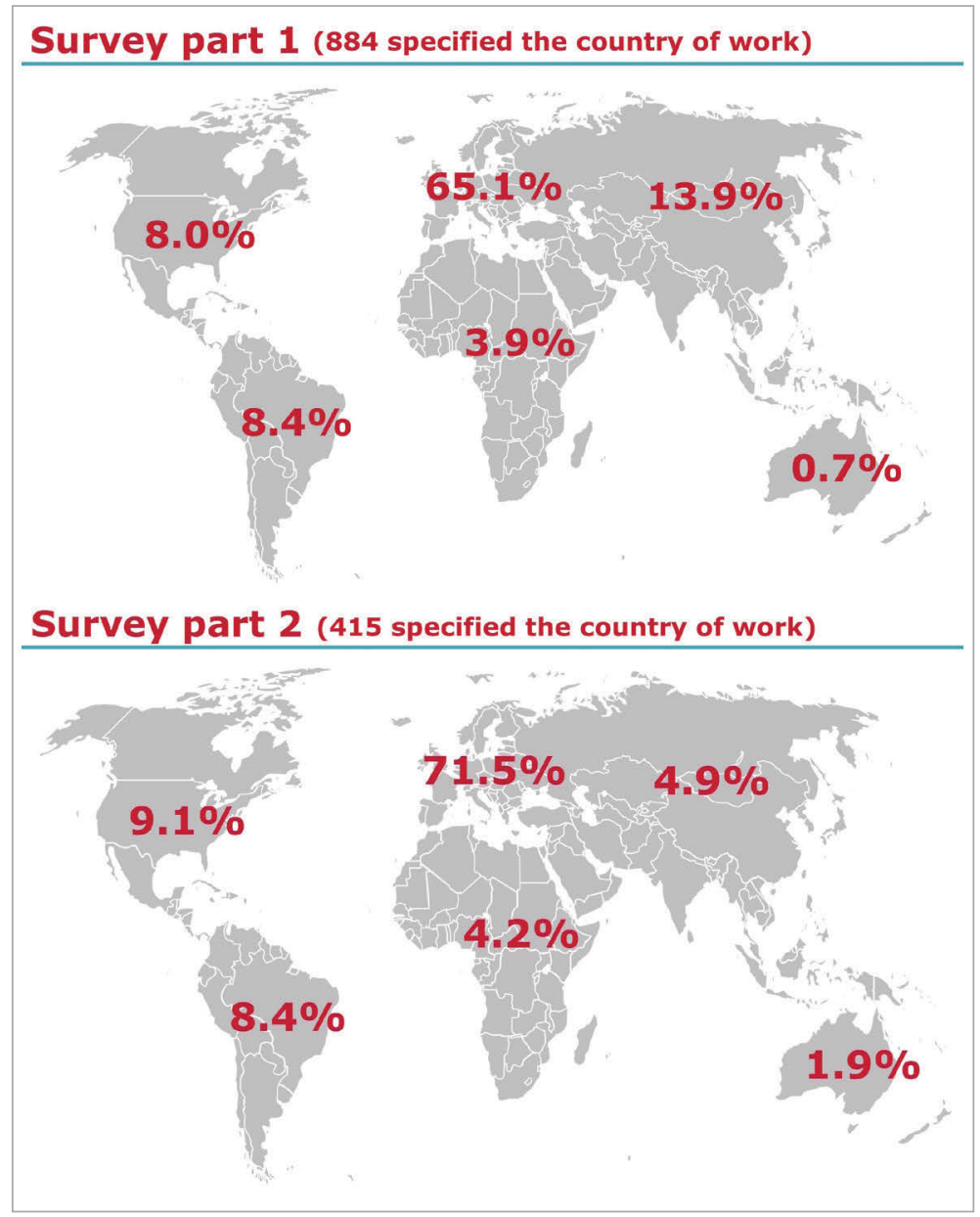

Online Figure 1. Geographic region of practice of the respondents. 